\title{
Orang Asli Semelai: Conflict of Defending Land Ownership Rights
}

\author{
${ }^{1}$ Azima A.M \\ 1Novel Lyndon \\ 2Sharifah Mastura S.A \\ 1Suhana Saad \\ ${ }^{1}$ Abdul Hair Awang \\ ${ }^{1}$ Associate Professor, Faculty of Social Sciences and Humanities, Universiti Kebangsaan Malaysia \\ azima@ukm.edu.my \\ ${ }^{2}$ Associate Professor, Faculty of Social Sciences and Humanities, Universiti Kebangsaan Malaysia \\ novel@ukm.edu.my \\ ${ }^{3}$ Professor, Institute of Climate Change, Universiti Kebangsaan Malaysia, 43600 Bangi, Selangor, Malaysia \\ sharifah@eoc.ukm.my@ukm.edu.my \\ ${ }^{4}$ Associate Professor, Faculty of Social Sciences and Humanities, Universiti Kebangsaan Malaysia \\ Suhana@ukm.edu.my \\ ${ }^{5}$ Associate Professor, Faculty of Social Sciences and Humanities, Universiti Kebangsaan Malaysia \\ hair@ukm.edu.my
}

\section{Doi:10.5901/mjss.2015.v6n4s3p63}

Abstract

This study focuses on the institutional constraints that prevent the Orang Asli (Indigenous People) from defending the ownership rights of their land. The emphasis on an institutional constraint is only focused on the elements of formal provisions such as Orang Asli land law. Analysis based on the use of institutional approach has found that there exist barriers in land ownership of Orang Asli Semelai or the Semelai indigenous people in the research area. Among the factors identified include Act 134 (Aboriginal Peoples Act 1954), Land Acquisition Act 1960, land deprivation, and weaknesses of the law. Constraints in the provision of Act 134 (Aboriginal Peoples Act 1954) were found to have huge implications on their land ownership issue. The inability of the current law to defend the issue of losing land ownership amongst the indigenous people results in several requirements of strategic actions to be carried out. Among the actions proposed are through the method of participatory mapping.

Keywords: Indigenous People, Conflict, Institution, Customary land and ownership

\section{Introduction}

The Orang Asli Semelai is the primary occupants in Tasek Bera since 600 years ago. The lake, fauna and flora, and the Orang Asli Semelai are the main attractions of Tasek Bera for visitors. Tasek Bera is a wetland of international importance or a Ramsar Site since 1995. The area designated as Ramsar Site is 31, 120 hectares. This largest natural lake in Malaysia is located about $70 \mathrm{~km}$ from Temerloh town and is linked by roads (Refer to map 1). According to the statistics of the Department of Orang Asli Affairs or Jabatan Hal Ehwal Orang Asli (JHEOA), there are currently 1,260 Semelai people who make up 238 families (Jabatan Orang Asli Malaysia, 2010). The cluster of Semelai tribe is currently scattered in the area surrounding Tasek Bera in the district of Temerloh in Pahang. At the moment, there are five Semelai villages in Tasek Bera, namely Kampung Putat, Baapak, Gau, Jelawat and Lengut or Kuin. The community of Semelai native people in Tasek Bera, Pahang, not only has connection with the land but they also have connections to the fresh water lake and the vegetation surrounding it. The belief of the Semelai people that each hole or depth in the lake has a guardian has resulted in the lake and their land to be preserved.

Hence, it is not surprising that the Semelai people give names to each depth of the lake with the names of god as the owner. This is because they believe that each has its own guardian; among these are jrolor (big hand of the lake), solok (small hand), and padar (swamp) ranoq (swamp forest). Presently, the skills of the Semelai people of the intricacies 
of Tasek Bera have made them the guides in the provision of boat and cruise services around the lake. This situation proves that the need of the cultural and spiritual survival of the community of the Orang Asli Semelai is dependent on land ownership and the existence of Tasek Bera itself. This is because according to the Tasek Bera Authorities, the life of the Semelai tribe cannot be separated from the existence of Tasek Bera, and indeed the land too. In fact, Article 8(5) (c) of the Federal Constitution and the Aboriginal Peoples Act 1954 clearly state that the Orang Asli or indigenous people have the rights to be protected in matters related to land.

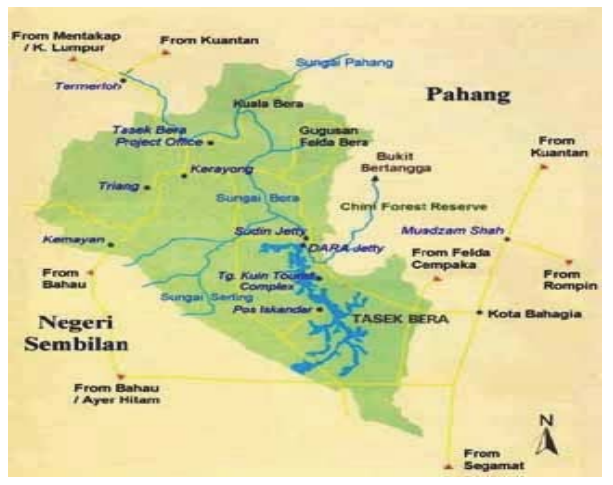

Source: http://www.Cfresort.com.

\section{Research Problem}

Orang Asli can be divided into three tribes which are the Negrito, Senoi and Melayu Asli. The term 'Orang Asli' is the term introduced by the government of Malaysia to replace the word 'aborigines' or 'sakai' that was used by the British administration during the colonial period which refers to the group of people who lives deep in the forests of this country. Furthermore, the term 'aborigines' describes a condition of a society that is backwards, primitive and wild. As the title does not reflect the reality of the state of this community or people, hence, the government of Malaysia suggested that these people are known as Orang Asli. The title of Orang Asli gives recognition to this group of people as the original inhabitants and the earliest indigenous group who settled in this country (Hasan Mat Nor 1996).

Apart from the life of the Semelai people, Tasek Bera which is rich in biodiversity has been recognized internationally as a Ramsar Site or the first wetland in this country in the year 1994 (Utusan Malaysia 1997). The diversity of the wetland habitat can be established and it used to be the main source of food for the Semelai people before they practiced farming practices and permanent settlements. However, the development of Tasek Bera as a Ramsar Site has brought changes to the life of the Semelai people from nomadic living to permanent settlement. In addition to the existence of development transformation that led to the need of land acquisition, these matters eventually explain the need to have clear land ownership amongst the Orang Asli community. Therefore, the focus of this discussion will first describe the aspects related to the Orang Asli and its relationship with land ownership. Meanwhile the next section will discuss the details of the barriers to land ownership by the Orang Asli from the perspective of economic institution to understand the barriers to land ownership amongst the Orang Asli community.

\section{Literature Review}

Indigenous people or Orang Asli are a group of native people in Peninsular Malaysia (Ramle 2007) and a group of people who has little contact with the outside world; in contrast, they have very close relationship with each other (Amir Zal et al. 2011 ). Indigenous people are also known as a community whose life is dependent on the forest and the natural environment by carrying out subsistence economic activities such as shifting cultivation, hunting and collecting forest products as well as fishing (Ramle 2001; Amri Zal et al. 2011).

The Constitution of Malaysia Article 160(2) states that "Orang Asli is only defined as the indigenous people of the Malay Peninsula". This means that only the indigenous people in the Peninsular can adopt the provision that has been outlined in the Malaysian Constitution, while the other races are considered as Bumiputera (natives). This is reinforced through Act 134 (Aboriginal Peoples Act) under clause 3 (1) that has given a specific definition of who can be accepted 
as Orang Asli or indigenous people. Therefore, a person who is said to be Orang Asli includes:

a) the person's father originates from any of the Orang Asli or indigenous ethnic groups

b) anyone who is adopted by the indigenous people or Orang Asli

c) the child of an indigenous people or Orang Asli woman with any man who is not an Orang Asli.

These individuals need to live as indigenous people, practice the language, beliefs and the customs of the indigenous people. If these conditions are met, hence the individual is considered as an indigenous person or Orang Asli by law. However, clause 3 (2) of the Aboriginal Peoples Act also points out that if an Orang Asli changes his religious beliefs, but still holds on to the customs of the indigenous people and converses in the language of the indigenous people, the individual is still accepted as an Orang Asli.

Framework of Orang Asli community land dispute or conflict: In the Malaysian context, there are several formal provisions/regulations that have led to the existence of the conflicts or disputes of land ownership amongst the Orang Asli with the implementing agents of development. Among them are Act 134 (Aboriginal Peoples Act 1954), Land Acquisition Act 1960, property deprivation and weaknesses of the law.

a) Act 134 (Aboriginal Peoples Act 1954): As the early group of people in this country, certainly the Orang Asli has the rights to getting protection and privileges of settling on the land. Therefore, Orang Asli actually is not exempted from having the rights to claim land ownership rights. However, the rights or the entitlement of the Orang Asli of the land has become an issue when land acquisition for the purposes of development in the Orang Asli reserve areas occurs. This matter is voiced by the Orang Asli community and among them:

"we only have the rights to occupy but not to own our land"

This matter clarifies that Act 134 does not provide the necessary protection for land ownership as well as does not allocate fair compensation if the land of the Orang Asli is taken for the purpose of development. In the meantime, Act 134 is a reference that fully empowers the government to define or interpret what can be done, what is possible or impossible for future development of the Orang Asli community.

Furthermore, there is a contradiction in the Aboriginal Peoples Act 1954 with the Land Provision Act 1965. As an example, Section 6 and 7 of the Aboriginal Peoples Act (Act 134) state that any land that has been declared as the Orang Asli reserve area is not a reserve for the purpose of Section 62 National Land Code 1965. Therefore, any area that is designated as the reserve area of Orang Asli is still considered as government land. This flaw has resulted in the efforts to gazette land as Orang Asli Gazetted Land very problematic. Furthermore, the ownership given to the Orang Asli is the right to live and not to own the land, not like the Malay gazetted land where the Malays can and have the right to hold their own land grant.

b) Land Acquisition Act 1960: Recognition of Orang Asli's rights to their traditional areas is clearly recorded according to Section 8 (1) Aboriginal Peoples Act 1954 which states:

"The State Authority may grant rights to occupy any land which is not land that is alienated or given ownership or land that is not leased for any purpose in any area of the Orang Asli or reserve of the Orang Asli"

This shows that the Orang Asli community has the right to occupy the land area but not to own the land which they occupy. Nevertheless, the Constitution has provided power to the Federal Government to create Reserve areas. Orang Asli are included in the Federal Register and provision to create reserve areas for Orang Asli is enshrined in Article 8 (5) which is:

Article 8 (5) does not annul or prohibit:

(c) any provision for the protection, well-being or development of the Orang Asli of the Malay Peninsula (including gazetting of land)...."

Therefore, in Section 13 Aboriginal Peoples Act 1954, it is stated that

When any immovable property, which is not government land is required to be taken to be declared as Orang Asli area or Orang Asli reserve area, the property can be taken according to the written law on land acquisition and any declaration that is required by the law that the property is required as such shall have effect as if it is a declaration that the property is required for public purpose according to the written law.

This section clearly explains that when the government takes any land that has been gazetted as Orang Asli 
reserve land for public purposes, the government is not obligated to replace or relocate the area that has been taken. It will only be replaced with compensation as contained in section 11 (1) and 12 which state

\begin{abstract}
"If an indigenous community can prove that a claim against fruit trees or rubber trees on any government land which is alienate, given or leased for any purpose, occupied temporarily under license or otherwise released, or if any rights or privilege in any Orang Asli area or Orang Asli reserve that is given to any Orang Asli or Orang Asli community is annulled in whole or in part, then the state authorities can give compensation for it and can pay compensation to the person or the people whom in their opinion is entitled to it or can, if they think fit, pay the compensation to the Commissioner to be kept by him as a collection of public fund for any person or any indigenous community as directed by the Minister, and to be administered according to the conduct prescribed by the Minister."
\end{abstract}

However, this provision clarifies that there exists no overall value of crops as contained in the First Schedule of the Land Acquisition Act 1960. In the case of Orang Asli reserve land, compensation will be given based on the losses contained on the land. This situation creates various problems to the Orang Asli because they usually do not carry out farming activities on the reserve land that they own. The question here is: is there any other available compensation that exists which can be given to the Orang Asli community in the event that their land is acquired for development purposes?

c) Deprivation of Orang Asli owned land: This situation has resulted in the reluctance of the indigenous community to return the land that they have long occupied to the government for a number of reasons, among which are the concerns of the Orang Asli toward the actions of the government not to replace or relocate the area that is taken to a new one. According to Hasan Mat Nor (1996), their anxiety should not be taken lightly as it can affect the attitudes and interests of the Orang Asli community toward the efforts of developing the land.

Additionally, most of the lands occupied by the Orang Asli community presently have not been gazetted as reserve land and most of them are still at the proposal stage status. The concern on this issue is clear when Orang Asli trespassing or intrusion occurs as they have no clear proof that the land is their right to use. Sometimes, the land that they use is not stated in the official records of the land office. This is a nightmare for the Orang Asli community who all this while has worked the land for generations but the reality is that the land is not theirs (Zawawi Ibrahim 1996).

In the meantime, many among the Orang Asli are aware that the government can relocate them to other areas at any time when the area has to be taken to be developed. Status as 'tenant at will' has limited the Orang Asli from using their land for the purpose of development, especially for those involved in economic activities based on market crops.

In addition, their ability to defend their land or reinforce their compensation claims should their land be taken by the government under section 3 of the Land Acquisition Act 1960 is quite limited. The compensation paid is very little because the assessment is made based on what is contained on the land only. When their land is taken, they will also lose their home and the development achieved on the land will also be destroyed. The implication is that the cultural and spiritual survival that has become the foundation of their existence as a community will also be affected.

d) Weaknesses of the Law for Gazetting Orang Asli Reserved Land: Significant marginalization occurs to the Orang Asli community arising from the provisions contained in the Malaysian constitution. As stated under Article 153 and 161A, the Malays as well as the Sabah and Sarawak indigenous people are given special rights that are protected by the Constitution of Malaysia. In contrast, for the Orang Asli community, it is not stated clearly as having the right to obtain protection and special privileges under the provisions of such laws. This is clarified by Hasan Mat Nor (1998) who mentioned that this is possibly because in the Constitution of Malaysia, Orang Asli is not defined as 'bumiputera' and because of that they are excluded from enjoying the special privileges as those enjoyed by the Malays. This explains the existence of loopholes in the Aboriginal Peoples Act 1954 that failed to explain the responsibility of the State Government toward the Orang Asli even though there are provisions in section 6 (1) and 7 (1) of the Aboriginal Peoples Act 1954 that empower the state authorities to gazette and declare any area that is occupied by the Orang Asli as Orang Asli Reserve Land.

\title{
4. Research Methodology
}

As this study focuses on the need to understand the factors that prevent or act as barriers to land ownership by the Orang Asli community, hence, an approach that focuses on institutional importance has been used. The empirical study of the Orang Asli Semelai in Tasek Bera aims to identify the institutional barriers in the context of formal rules that is a constraint to the Orang Asli community in defending their ownership rights of Orang Asli's customary land. Based on the outcome of the discussion with the Department of Orang Asli Affairs (JHEOA), the Semelai people of Tasek Bera were 
chosen as the research site. The results of the study were obtained through in-depth interviews with the Orang Asli Semelai in Tasek Bera Pahang. The study which is based on in-depth interviews is aimed at understanding the factors that led to the existence of conflicts in land ownership amongst the Semelai community with development agencies. In order to enable interpretation and explanation in relation to the conflict to be examined well, hence, the economic institutional approach was used as the study's framework to discuss the issues that led to the land ownership conflict amongst the Semelai indigenous people.

\section{Results and Discussion}

\subsection{Experience from the barriers of land ownership by the Orang Asli}

The discussion above explains that there are four main factors that prevent land ownership by the Orang Asli community. Among them is Act 134 (Indigenous Peoples Act 1954), Land Acquisition Act 1960, property deprivation as well as the weaknesses of the existing land law. This is consistent with the findings of the study carried out by Colchester et al. (2012) which found that there exist various barriers for the adat community in defending their ownership rights of land. Among the barriers identified are social prejudice, land ownership law, resource barriers, capability, lack of awareness among the community to take advantage of the provisions of the existing law, social assimilation policy, racial and service elements in the administration of land that are inflexible. Nevertheless, in the context of the Orang Asli in Malaysia, land ownership barriers are more related to legal restrictions of land ownership as well as inflexible services in land administration. This situation in the end induces various conflicts and subsequently creates the feelings of dissatisfaction among the indigenous customary land owners.

As an example, the report prepared by the local newspaper on 27 May 2009 explained that the native people in Sarawak are working to safeguard their customary land from being continuously acquired for development purposes. Amendment of the land law Part 18 in 1997 authorises the Superintendent of the Land and Survey Department to consolidate the abandoned customary lands by declaring the development area as considered to have affected the rights of the native inhabitants such as the Ibans, Orang Ulu and Bidayuhs, and even the Malays. In addition, the land amendment of 2000 that has repealed the sociocultural component of land ownership as stated in Part 5(2)f has also opened up the opportunity as well as enabled the private parties to develop the land that was once owned by the local community.

At the same time, flaws in the issue of land ownership as a result of the weaknesses of the existing law can also be examined in the context of NCR land (Native Customary Rights Land) in Sarawak, as an example. In Sarawak, disputes related to ownership between the community with the agencies and the federal government often occur. Disputes between the communities in the context of land ownership are driven by two main factors, namely delimitation of NCR land using oral information such as vegetation, hills, rivers, and oral narratives from one generation to another as the basis of land delimitation. The second weakness touches on the question of the existing conventional mapping because it fails to take into account the oral or informal information when the land delimitation work is being carried out. This situation gives rise to overlaps and subsequently may lead to disputes because the information related to the local information such as culture is not taken into account in the land delimitation (Azima 2014).

Returning to the issue of obstacles in land ownership of the Orang Asli or indigenous people, a study by Colin Nicholas (2007) found that the Orang Asli in Malaysia are still controlled by Act 134 where he characterises it as an act that is outdated and confining in nature from facilitating development and preservation of the welfare of the Orang Asli. Furthermore, this Act is found as not giving total protection at all to the Orang Asli land, in addition to not allocating fair compensation. An example is the case that is related to the Orang Asli community in Bukit Tampoi. Court action had to be taken to obtain fair compensation on the intrusion and forced acquisition of their customary land and village. It is understood that up to the present time, even though the decision is in favour of the Orang Asli, the government still does not want to accept it. This is explained further with their views:

\footnotetext{
..."Because of Act 134, the Orang Asli community seems to be blocked from making decisions as well as determining for themselves what is good for us..."
}

In the case of the Tew Teras Village, it involved 330 acres of land that were taken over by FELDA Besut without any detailed negotiation and explanation with the villagers. This situation proves that Act 134 has opened up the opportunity for the Orang Asli to be exploited, in addition to the existence of weaknesses in the provisions on compensation where the payment only takes into account crops as well as the discretion of the Orang Asli Commissioner 
and not calculation based on market value of the land.

The loss of land by the native people as a result of the weaknesses or loopholes of the existing land law will also have implications on the customs and the culture of the Orang Asli community. These laments on land loss that will affect the customs and culture are also acknowledged when the majority of them state that:

..." the aspects of our life are closely linked to the land..."

This is because the main problem that is faced by the Orang Asli in respect to the customary land is intrusion, exploitation and land acquisition by others. Problems arise because of the lack of gazetting and no gazetting on the areas where it is indeed known as being occupied by the Orang Asli (Colin Nicholas 2007). This matter places the Orang Asli in danger because the existing law fails to protect their wellbeing or their interests of the land.

Referring to the case in Sarawak, the market for customary land does not necessarily have to follow the regimes of demand and supply. This is because the price of customary land typically is determined by the government which is at the rate of around RM1, 200 per hectare (Dimbab, 2007). Even though the demand of the private sector on customary land for commercial purposes is on the rise, especially for the development of palm oil estates, land supply has not increased. This is because customary land owners, namely the local community is not interested to work together because they are worried that they will lose the land for their future generation. Furthermore, the local community does not have any clear description in connection with the benefits to be obtained from their land acquisition. The failure to take into account the benefits of the local people in connection to the acquisition of their customary land can be explained in terms of management. Aspects of sustainable development of customary land is only managed conventionally which merely emphasizes on the elements that are connected to the strategic actions in comparison to communicative action (Stephan et al. 2007). These strategic actions ignore the local perspective. This is not appropriate with the culture and values of the Sarawak indigenous people. Development approach that is based on communicative approach is more appropriate in customary land areas.

\section{Conclusion}

Based on the discussion, there exists a clear description related to the concerns of the Orang Asli community that they will lose their land as a result of the intrusion, exploitation and acquisition of land. The strategic action of the government that ignores the local perspective on the culture and value of the community toward the land will only lead to disputes or conflicts between the interested parties in the development. In order to overcome the conflict of the local community on the issue of ownership amongst the Orang Asli community in Malaysia, the approach of community participation should be used to replace the conventional mapping approach. This is necessary to enable the local community to defend their rights to the customary land that is owned and avoid disputes in ownership. Therefore, a participatory digital mapping approach that is friendlier toward the local community who has interests in the NCR land is genuinely required.

\section{Acknowledgements}

This research was supported by Grant Research Chair in Climate Change UKM-Sime Darby Foundation (ZF-2013-013).

\section{References}

Azima Abdul Manaf. (2014). Menangani cabaran tranformasi Tanah NCR: Satu keperluan terhadap pendekatan pemetaan berpenglibatan. Malaysian Journal of Society and Space.10 issue 1 (110 - 117).

Colchester M, Griffiths T, McKay F, Nelson J (2004) Indigenous land tenure: Challenges and possibilities. In: Land reform, land settlement and cooperatives. Food \& Agriculture Organization of the United Nations (FAO).

Dahlan, H.M. (1998). Persoalan Pribumi dalam pembangunan. In Hasan Mat Nor (ed.).Warga Pribumi menghadapi cabaran pembangunan, pp. 16. Department of Anthropology and Sociology. Bangi. Universiti Kebangsaan Malaysia.

Dimbab Ngidang (2007) Kuasa pasaran, ruang tanah adat dan pembangunan tanah di Sarawak.

International Seminar on Tanah Keterhakisan Sosial dan Ekologi: Pengalaman Malaysia dan Indonesia. Organised by Dewan Bahasa dan Pustaka and The Institute of the Malay World and Civilisation (ATMA) Universiti Kebangsaan Malaysia. 4-5 December.

Gomes. A. G. \& Anthony, W.H. (1993). Masyarakat Senai di Perak : Satu Tinjauan Etnografi. In Hood Salleh, Kamaruddin M. Said and Awang Hasmadi Mois(eds.). Mereka yang terpinggir : Masyarakat Terasing Indonesia dan Orang Asli di Malaysia; pp. 91-96. Department of Anthropology and Sociology. Bangi. Universiti Kebangsaan Malaysia.

Hasan Mat Nor, Shahruddin Idrus and Sarah Aziz Abd. Ghani Aziz (eds.). (2001). Round Table Dialogues. Institute for Environment and Development (LESTARI). Bangi. Universiti Kebangsaan Malaysia. 
Hasan Mat Nor and Zanisah Man. (2011). Mencari diri,meniti perubahan dalam membentuk realiti impian menjadi warga 1Malaysia. Seminar Orang Asli Kesepaduan Sosial dan 1 Malaysia. Organised by Department of Museum Malaysia in cooperation with Institute for Ethnic Studies (KITA) UKM. 28 June 2011.

W.A. Amir Zal, Ma'rof Redzuan,Asnarukhadi Abu Samah and Hanina H.Hamsan. (2011).

Modal sosial dan hubungannya dengan pendayaupayaan ekonomi orang Kuala,Johor. Seminar Orang Asli Kesepaduan Sosial dan 1 Malaysia. Organised by Department of Museum Malaysia in cooperation with Institute for Ethnic Studies (KITA) UKM. 28 June 2011.

Hood Salleh. (1993). Pengajian Orang Asli dalam konteks masyarakat Malaysia. In Hood Salleh, Kamaruddin M.Said and Awng Hasmadi Moin (eds.). Mereka yang terpinggir : Masyarakat Terasing Indonesia dan Orang Asli di Malaysia, pp. 30 -39. Department of Anthropology and Sociology. Bangi. Universiti Kebangsaan Malaysia.

Husin Ali. (1976). Apa Erti Pembangunan?. Dewan Bahasa dan Pustaka.

Jabatan Hutan dan Renjer Gombak. Forestry Manual 2003 Volume 111. (2005). Jabatan Perhutanan Semenanjung Malaysia. October 2005. Kuala Lumpur.

Jabatan Hal Ehwal Orang Asli Malaysia. (2004). Kuala Lumpur. Wisma Selangor Dredging.

Jabatan Hal Ehwal Orang Asli, Malaysia. (2010). Online: www.jheoa.gov.my. Printed on 15 March 2010.

Jomo K.S. and Noorkahairil Huda M. Ali. (2001). Aliran Pemikiran Ekonomi, Kenapa Ahli Ekonomi Tidak Sependapat ?. Kuala Lumpur. Dewan Bahasa dan Pustaka.

Lim, H.F. (1997). Orang Asli, Forest and Development. Forest Research Institute Malaysia, Kepong, 52109 Kuala Lumpur, Malaysia.

Nicholas, Colin. (2000). The Orang Asli and The Contest for resources : Indigenous.Politics, Development and Identity in Peninsular Malaysia. Kuala Lumpur. Vinlin Press Sdn. Bhd. Dewan Bahasa dan Pustaka.

Romanus Bin Andrew. (2003). Kesan Rancangan Penempatan Semula (RPS) terhadap kegiatan ekonomi masyarakat Orang Asli Jakun: Kajian Kes di Mukim Bekok, Segamat. Penerbit Universiti Kebangsaan Malaysia.

Rozalli Hashim. (2005). Pengajian Pembangunan. Dewan Bahasa dan Pustaka.

Stephan R, Mani C, Cesar E, Anne Z. (2007). Moving from sustainable management to sustainablegovernancee of natural resources: The role of social learning processes in rural India, Bolivia and Mali. Journal of Rural Studies 23 (1), 23-37.

Shamsul Amri Baharuddin. (1972). Satu Kajian Etnografi Orang Asli Senoi- Semai di Pos Telanok, Tanah Rata, Pahang. Jurnal Manusia dan Masyarakat, No.1, Department of Anthropology and Sociology. Kuala Lumpur. Universiti Malaya.

Wan Halim Wan Othman. (1993). Panduan Pembinaan Warga Malaysia. Kuala Lumpur. The Institute for Policy Research (IKD).

Taman Rimba Komanwel. (2008). Online http://www.Cfresort.com. Printed on 15 March 2008.

Utusan Malaysia. Asal-usul suku kaum Semelai. 24/5/1998.

Utusan Malaysia. Tasek Bera Khazanah Negara. 1/11/1997. 